\title{
Tetraselmis chuii biomass as a potential feed additive to improve survival and oxidative stress status of Pacific white-leg shrimp Litopenaeus vannamei postlarvae
}

\author{
Norazira Abdu Rahman • Helena Khatoon • Norhayati Yusuf • \\ Sanjoy Banerjee • Noor Azilah Haris · Fathurrahman Lananan • \\ Katayama Tomoyo
}

Received: 7 March 2017/ Accepted: 10 August 2017/Published online: 20 August 2017

(C) The Author(s) 2017. This article is an open access publication

\begin{abstract}
Shrimp is an important traded fishery commodity. When subjected to stress, shrimp usually suffers from oxidative stress, which leads to cell injury, senescence, and death. To maintain shrimp good health, performance and production, antioxidant and immune systems are important. Natural antioxidants found in microalgae may be used to increase the cell protection against oxidative damage, being a promising alternative to the carcinogenic synthetic antioxidants. In this study, Tetraselmis chuii was evaluated for its effect on survival, growth and oxidative stress biomarkers on Litopenaeus vannamei postlarvae (PL). The antioxidant properties of the formulated feed with $T$. chuii inclusion were determined using four antioxidant chemical assays. Meanwhile, the oxidative stress biomarkers on PL were analyzed by hydrogen peroxide, membrane stability and lipid peroxidation assays. Results showed that PL reared on diets supplemented with $50 \%$ T. chuii had a significantly higher $(P \leq 0.05)$ survival $(97.6 \pm 1.4 \%)$ and lower oxidative stress in terms of hydrogen peroxide content $\left(10.08 \pm 0.4 \mathrm{mM} \mathrm{g}^{-1} \mathrm{FW}\right)$ and electrolyte leakage $(10.8 \pm 0.3 \%)$. The result of this study also showed that shrimp PL reared on diets supplemented with microalgal, $T$. chuii have high resistance to reverse salinity stress test $(76.7-100 \%)$. However, no significant differences $(P \geq 0.05)$ were found in the growth and lipid peroxidation. Due to the positive effect on oxidative stress status, survival and resistance to salinity stress, the feeding of L. vannamei PL with diet containing at least $50 \%$ of $T$. chuii is recommended as a natural source of antioxidant for PL.
\end{abstract}

N. A. Rahman

School of Fisheries and Aquaculture Sciences, Universiti Malaysia Terengganu, 21030 Kuala Terengganu, Malaysia

H. Khatoon $(\bowtie) \cdot$ N. A. Haris

Institute of Tropical Aquaculture, Universiti Malaysia Terengganu, 21030 Kuala Terengganu, Malaysia

e-mail: hlnkhatoon@gmail.com

N. Yusuf

School of Science and Technology, Universiti Malaysia Terengganu, 21030 Kuala Terengganu, Malaysia

S. Banerjee

Institute of Bioscience, Universiti Putra Malaysia, Serdang, Malaysia

F. Lananan

East Coast Environmental Research Institute, Sultan Zainal Abidin University, Gong Badak Campus,

21300 Kuala Terengganu, Terengganu, Malaysia

K. Tomoyo

Graduate School of Agricultural and Life Sciences, The University of Tokyo, 1-1-1, Yayoi, Bunkyo-ku, Tokyo 113-8657, Japan 
Keywords Marine Microalgae · Antioxidant · Feed supplement · Oxidative stress biomarkers · Shrimp

\section{Introduction}

Litopenaeus vannamei (white-leg shrimp) is the most widely cultivated penaeid shrimp in many parts of the world, especially in the Southeast Asian region. However, shrimp aquaculture production is challenged by pathogenic infection, low survival, weak larvae, and environmental problems, which results in significant loss of production (Lightner 2011). In aquatic organisms, changes in the environmental condition, such as salinity, oxygen levels, and temperature, can enhance the generation of reactive oxygen species (ROS), causing oxidative damages in tissues (Lushchak 2011). Thus, physiological conditions such as antioxidant system are critical for shrimp health maintenance and healthy growth performance, especially under environmental stress (Castex et al. 2010). Failure in detoxifying the excess ROS production using their natural antioxidant defenses may lead to significant oxidative damages. Some of these include the inactivation of enzymes, degradation of the protein, DNA damages and lipid peroxidation (Di Giulio et al. 1995). These damages may lead to a disease outbreak and huge economic losses (Bachère 2000).

Commercial antioxidant supplements such as butylated hydroxytoluene (BHT) and butylated hydroxyanisole (BHA) have been incorporated into the feed to reduce the oxidative damage in aquatic animals. However, the utilization of both synthetic antioxidant has already been restricted due to their carcinogenic and toxic nature in animal models (Liu et al. 2007). This leads to the search for natural sources of antioxidant compounds instead of relying on the dangerous synthetic ones. In recent years, besides their important roles and application in aquaculture hatcheries, microalgae have also attracted increasing attention as animal feed supplement since they are a rich source of natural antioxidants, pigments, and other bioactive compounds. Microalgae of different genera and species have been found to exhibit significant antioxidant activity in vitro (Geetha et al. 2010; Rao et al. 2006) and, thus, they are considered as potential natural sources of antioxidants in vivo. In addition, most microalgal extracts showed a much higher inhibition of liver microsomal lipid peroxidation compared to BHT which is one of the most powerful synthetic antioxidant agents (AbouL-Enein et al. 2003).

Marine microalgal, Tetraselmis sp. are flagellated chlorophytes with rapid growth rate, and can stand a broad range of temperatures and $\mathrm{pH}$ values (Khatoon et al. 2014). Tetraselmis sp. is a widely used species in aquaculture as it contains adequate amounts of protein, lipid, carbohydrate and fatty acids which are essential for the cultured organisms. This species also serves as a rich source of a variety of bioactive compounds, such as vitamin E, carotenoids, phenolic compounds, and terpenes, which have antioxidant, anticancer and antimicrobial properties (Jahnke 1999; Carballo-Cárdenas et al. 2003; Ismaiel et al. 2016). Although there are already some species that has been produced commercially and studied for their potential as feed supplements, such as Spirulina and Haematococcus pluvialis, there is still need to search for the next best microalgae species. Many studies on microalgae as food additives in aquatic farmed animals focused on survival, growth, nutrition and pigmentation of the species (Ju et al., 2011, 2012; Macias-Sancho et al. 2014; Li et al. 2014). However, no studies have been reported on the efficacy of Tetraselmis sp. on the oxidative stress in $L$. vannamei postlarvae. The aim of the present study was to evaluate the effects of $T$. chuii supplementation on growth, survival and oxidative stress status in L. vannamei postlarvae. This study highlighted the potential of these microalgae when utilized as a natural source of exogenous antioxidant and their ability to enhance the shrimp defenses against oxidative stress and damage.

\section{Materials and methods}

Culture of microalgae

Tetraselmis chuii were obtained from the laboratory of the Institute of Tropical Aquaculture, Universiti Malaysia Terengganu. The pure $T$. chuii was cultured and maintained at $25^{\circ} \mathrm{C}, 30 \mathrm{ppt}$ salinity using Conway medium (Tompkins et al. 1995) and $24 \mathrm{~h}$ photoperiod. Conway medium was prepared by adding macronutrient $(1 \mathrm{~mL})$, trace metals $(0.5 \mathrm{~mL})$ and vitamins $(0.1 \mathrm{~mL})$ stock solution to $1 \mathrm{~L}$ of filtered and sterilized 
seawater (Tompkins et al. 1995). Subculturing of microalgal stock culture was done once in two weeks to maintain the health and purity of the stock. The stock culture was used for the culture experiments.

Tetraselmis chuii was cultured in $25 \mathrm{~L}$ closed cylinder photobioreactors under laboratory conditions using Conway medium according to Khatoon et al., (2014). The initial cell density for each culture was at $1 \times 10^{5}$ cells $\mathrm{mL}^{-1}$. Cultures were maintained under a light intensity of $50 \mu \mathrm{mol}^{-2} \mathrm{~s}^{-1}$ at $25{ }^{\circ} \mathrm{C}$ and $24 \mathrm{~h}$ continuous light using white fluorescent light. Aeration was provided continuously throughout the culture. Once the culture reached their stationary phase (on day 8), the cells were harvested by centrifugation at $8000 \mathrm{rpm}$ for 10 min using a tubular continuous centrifuge J-025 (Hanil Science Industrial Co.LTD). Samples were then freeze dried using Labconco Freezone 4.5 and kept at $-20{ }^{\circ} \mathrm{C}$ until further use.

Feed formulation for L. vannamei postlarvae

The freeze-dried microalgal T. chuii was ground using a stand mixer (KitchenAid ${ }^{\circledR}$ Professional 600 Series, Michigan, USA). Then, formulated feed was prepared by incorporating commercial feed with microalgal $T$. chuii at $25 \% \mathrm{w} / \mathrm{w}, 50 \% \mathrm{w} / \mathrm{w}, 75 \% \mathrm{w} / \mathrm{w}$ and $100 \% \mathrm{w} / \mathrm{w}$. A commercial feed commonly used for the production of $L$. vannamei at this rearing phase was used as the control diet. The formulated feed was then milled to $300 \mathrm{~mm}$. The formulated feeds were then kept at $-20{ }^{\circ} \mathrm{C}$ until further use.

Determination of antioxidant properties

\section{Preparation of samples extracts}

The formulated feed (with different percentages of dried microalgal T. chuii) was used in this experiment. Sample extracts were prepared by adding $12.5 \mathrm{~mL}$ distilled water to $0.1 \mathrm{~g}$ of dried formulated feed before it was incubated in $100{ }^{\circ} \mathrm{C}$ water bath for an hour (Gyamfi et al. 1999). Then, it was centrifuged for $10 \mathrm{~min}$ at $10,000 \mathrm{rpm}$ using a high-speed refrigerated centrifuge (Hitachi CR22N, Japan). The supernatant was stored at $4{ }^{\circ} \mathrm{C}$ and used as the extract.

\section{Antioxidant activity}

Antioxidant activity was determined following the method of Yang et al. (2000). Linoleic acid emulsion ( $10 \mathrm{mM}, \mathrm{pH}$ 6.5) was prepared by dissolving $0.28 \mathrm{~g}$ linoleic acid (Sigma-Aldrich) and $0.28 \mathrm{~g}$ Tween 20 (Sigma-Aldrich) in $50 \mathrm{~mL}$, sodium phosphate buffer $(0.2 \mathrm{M}, \mathrm{pH}$ 6.5). Then, sample extract was added to $2 \mathrm{~mL}$ linoleic acid emulsion before it was incubated in the dark for $15 \mathrm{~h}$ at $37{ }^{\circ} \mathrm{C}$ to accelerate oxidation. Then, $6 \mathrm{~mL}$ of $60 \%$ methanol (HmbG Chemicals) was added before the absorbance was taken at $234 \mathrm{~nm}$ using a spectrophotometer (Shimadzu UV-1601, Japan) before and after oxidation.

\section{Scavenging effect on diphenyl-1-picrylhydrazyl radical}

Scavenging action of diphenyl-1-picrylhydrazyl (DPPH) radical was analyzed according to Shimada et al. (1992). One $\mathrm{mL}$ sample extract was added to $0.25 \mathrm{~mL}$ of DPPH radicals $(0.2 \mathrm{mM})$ (Sigma-Aldrich) in methanol (HmbG Chemicals) before it was incubated for $30 \mathrm{~min}$ at room temperature. The absorbance was then taken at $517 \mathrm{~nm}$ using a spectrophotometer (Shimadzu UV-1601, Japan) to measure the reduction of the DPPH free radical. One mL Trolox (Sigma-Aldrich), Ascorbic acid (Sigma-Aldrich) and BHT (SigmaAldrich) were also used at $20 \mathrm{mM}$ as positive controls. The scavenging effect on DPPH radical (\%) was calculated with the following equation: Scavenging effect $(\%)=\frac{\left(A-A_{1}\right)}{A} \times 100$, where $A$ was the absorbance of the negative control (DPPH solution only), and $A_{1}$ was the absorbance of the test sample.

\section{Scavenging effect on superoxide radical}

Superoxide anion was determined according to Robak and Gryglewski (1988) by adding $0.5 \mathrm{~mL}$ NADH $(78 \mu \mathrm{M}), 0.5 \mathrm{~mL} \mathrm{NBT}(50 \mathrm{mM}), 0.5 \mathrm{~mL}$ phenazine methosulfate $(10 \mu \mathrm{M})$ and $1.0 \mathrm{~mL}$ of sample extract to 
$0.5 \mathrm{~mL}$ Tris-HCl buffer $(16 \mathrm{mM}, \mathrm{pH} 8.0)$. The absorbance was then measured at $560 \mathrm{~nm}$ using a spectrophotometer (Shimadzu UV 1601). $20 \mathrm{mM}$ Ascorbic acid, Trolox, and BHT were used as the positive controls. The inhibition ratio $(\%)$ was calculated with the following equation: Scavenging effect $(\%)=\frac{\left(A-A_{1}\right)}{A} \times 100$, where $A$ was the absorbance of the control, and $A_{1}$ was the absorbance of the test sample. All chemicals used in this analysis were obtained from Sigma-Aldrich.

\section{Ferric reducing antioxidant potential assay}

The ferric reducing antioxidant potential (FRAP) assay was carried out following the method of Hajimahmoodi et al. (2010). Firstly, FRAP reagent was prepared prior to use by mixing $5 \mathrm{~mL}$ of a TPTZ solution (2,4,6-tripyridyl-S-triazine) (Sigma-Aldrich) $\left(10 \mathrm{mM} \mathrm{L}^{-1}\right)$ in $\mathrm{HCl}\left(40 \mathrm{mM} \mathrm{L}^{-1}\right)$ with $5 \mathrm{~mL}$ of $\mathrm{FeCl}_{3}(20 \mathrm{mM}$ $\left.\mathrm{L}^{-1}\right)$ (Sigma-Aldrich) and $50 \mathrm{~mL}$ of acetate buffer $\left(0.3 \mathrm{M}, \mathrm{pH}\right.$ 3.6) before it was warmed to $37^{\circ} \mathrm{C}$. Then, a $100 \mu \mathrm{L}$ sample extract was added to $3 \mathrm{~mL}$ of FRAP. The mixture was then incubated at $37{ }^{\circ} \mathrm{C}$ for $10 \mathrm{~min}$, and the absorbance was taken at $593 \mathrm{~nm}$. The results were expressed as micromole of Trolox equivalent.

Proximate analysis of the formulated diet

\section{Protein analysis}

Protein analysis was carried out according to Lowry et al. (1951). Each formulated feed (5-6 mg) was dissolved in $25 \mathrm{~mL}$ distilled water and $0.5 \mathrm{~mL}$ was taken from each diluted sample for protein analysis. Mixed reagent was prepared by adding $1 \mathrm{~mL}$ of Reactive 1 (1\% Potassium sodium tartrate) to $50 \mathrm{~mL}$ of Reactive 2 ( $2 \mathrm{~g}$ of Sodium carbonate) in $100 \mathrm{~mL}$ of $0.1 \mathrm{M} \mathrm{NaOH}$. Then, $0.5 \mathrm{~mL}$ of sample was added to $0.5 \mathrm{~mL}$ of $1 \mathrm{M}$ Sodium hydroxide and it was incubated for $5 \mathrm{~min}$ in $100{ }^{\circ} \mathrm{C}$ water bath. After $10 \mathrm{~min}$ of cooling in water bath, $2.5 \mathrm{~mL}$ of the mixed reagent and $0.5 \mathrm{~mL}$ of Folin reagent were added to the mixed solution and were kept in the dark places for $30 \mathrm{~min}$. The absorbance was measured using UV-1601 spectrophotometer (Shimadzu) at $750 \mathrm{~nm}$.

\section{Lipid analysis}

Lipid analysis was conducted according to Marsh and Weinstein (1966). The carbonization was carried out using tripalmitin as the standard after lipid extraction was performed following Bligh and Dyer (1959). Sample extraction was carried out by adding $4.5 \mathrm{~mL}$ of chloroform: methanol (1:2) to the sample before it was centrifuged at 10,000 rpm for $10 \mathrm{~min}$. The supernatant was separated and kept in a clean tube. The biomass was again extracted by centrifuging after adding $1.5 \mathrm{~mL}$ of chloroform and $1.5 \mathrm{~mL}$ of distilled water. Both supernatants were combined and evaporated with a water bath at $35^{\circ} \mathrm{C}$ under vacuum after the polar phase was removed. Two $\mathrm{mL}$ of concentrated sulfuric acid was added after it completely dries and the mixture solution was then cooled down to $0{ }^{\circ} \mathrm{C}$ immediately. The absorbance was then taken at $375 \mathrm{~nm}$ after $3.0 \mathrm{~mL}$ of distilled water was added to the mixture.

\section{Carbohydrate analysis}

The sample solution was prepared by adding $5-6 \mathrm{mg}$ of sample into $25 \mathrm{~mL}$ of distilled water (Dubois et al. 1956). Then, $1.0 \mathrm{~mL}$ of phenolic solution $(5 \%)$ and $5.0 \mathrm{~mL}$ of sulfuric acid were added to the sample solution before the absorbance was taken at $488 \mathrm{~nm}$, spectrophotometrically (Shimadzu UV-1601, Japan).

\section{Experimental setup}

The experiment was conducted at the Institute of Tropical Aquaculture, Universiti Malaysia Terengganu, Malaysia. Five treatments consist of $100 \%$ commercial feed (CF) as control; commercial feed with $25 \% \mathrm{~T}$. chuii supplement (T25); commercial with 50\% T. chuii supplement (T50); commercial feed with 75\% T. chuii 
supplement (T75) and 100\% T. chuii (T100). Fifteen $30 \mathrm{~L}$ rectangular aquaria filled with $20 \mathrm{~L}$ of filtered, dechlorinated seawater at $30 \mathrm{ppt}$ salinity was prepared.

The L. vannamei PL stage five (PL5) with average initial weight of $0.45 \mathrm{mg}$ was obtained from a commercial hatchery and stocked at a density of $50 \mathrm{PL} \mathrm{L}^{-1}$. Constant aeration was provided to each aquarium and the hatchery tanks were maintained under a $12 \mathrm{~h}$ light: $12 \mathrm{~h}$ dark cycle. The shrimps were fed four times a day at $6 \mathrm{~h}$ intervals with the formulated diet and Artemia (Golden Dolphin, Malaysia). The shrimps were fed with artemia, ad libitum (Gamboa-Delgado and Le Vay 2009). All treatments were done in triplicates and were carried out for 12 days. Fecal matter and the remainder of the uneaten food were siphoned out daily at less than $10 \%$ of the culture volume to maintain water quality. On the final day of the culture, surviving PLs from every treatment tank were counted and weighed to estimate mean survival for each of the treatments and the control groups. The shrimp PL tissue samples were collected and kept at $-80{ }^{\circ} \mathrm{C}$ for the oxidative stress biomarker analysis.

\section{Physical and chemical analysis}

Temperature, $\mathrm{pH}$, salinity and dissolved oxygen in the culture tanks were measured daily using a portable multi-parameter probe (YSI 556 MPS, USA). Meanwhile, total ammonia nitrogen (TAN), nitrite nitrogen $\left(\mathrm{NO}_{2}-\mathrm{N}\right)$ and phosphate phosphorous $\left(\mathrm{PO}_{4}-\mathrm{P}\right)$ were determined every other day (Parsons et al. 1984).

\section{Biological analyses}

The specific growth rate (SGR) of PL was calculated from the body weight based on Ricker's model (1990): $\mathrm{SGR}=\left(\frac{\ln _{\mathrm{wf}}-1 \mathrm{n}_{\mathrm{wi}}}{\Delta t}\right) \times 100$, where wf is the weight at time $(t)$ and wi is the initial weight of PL. At the end of the feeding experiment, the survival of PL for each treatment was calculated and reverse salinity stress test was conducted. The reverse salinity stress test is commonly practiced by commercial hatcheries to distinguish between healthy and weak PL (Khatoon et al. 2007). The stress test was carried out by transferring the shrimp PL from the culture tanks with $30 \mathrm{ppt}$ salinity to freshwater $(0 \mathrm{ppt})$ and the shrimp PL survival was recorded after $2 \mathrm{~h}$.

Oxidative stress biomarker analysis

\section{Hydrogen peroxide assay}

Level of hydrogen peroxide $\left(\mathrm{H}_{2} \mathrm{O}_{2}\right)$ was measured in the shrimp tissue collected on the final day of culture (Velikova et al. 2000). The fresh shrimp tissue sample $(0.15 \mathrm{~g})$ was homogenized at $0-4{ }^{\circ} \mathrm{C}$ in $1.0 \mathrm{~mL}$ of $0.1 \%$ trichloroacetic acid (TCA) (Sigma-Aldrich) before it was centrifuged for $10 \mathrm{~min}$ at 10,000 rpm. Then, $0.5 \mathrm{~mL}$ of supernatant was mixed with $0.5 \mathrm{~mL}$ of potassium phosphate buffer $(10 \mathrm{mM}, \mathrm{pH} 7.0)$. One $\mathrm{mL}$ potassium iodide was added to the mixture before it was incubated under dim light for $10 \mathrm{~min}$. The absorbance was measured at $390 \mathrm{~nm}$, using UV1601 spectrophotometer (Shimadzu).

\section{Lipid peroxidation assay}

Lipid peroxidation level was determined following the method of Heath and Packer, (1968). Fresh shrimp sample $(0.15 \mathrm{~g})$ was homogenized at $0-4{ }^{\circ} \mathrm{C}$ in the presence of $1.0 \mathrm{~mL}$ of $0.1 \%$ TCA solution before it was centrifuged at 10,000 rpm for $5 \mathrm{~min}$. Then, $2.25 \mathrm{~mL}$ TBA reagent was added to $0.75 \mathrm{~mL}$ of the supernatant. The TBA reagent was prepared by dissolving $0.5 \mathrm{~g}$ TBA (Sigma-Aldrich) in $100 \mathrm{~mL}$ of $20 \%$ TCA. The mixture was then placed in $95{ }^{\circ} \mathrm{C}$ water bath for 30 min and quickly cooled in ice bath for $15 \mathrm{~min}$. Then, it was then centrifuged at 10,000 rpm for 10 min before the absorbance was measured at $532 \mathrm{~nm}$ and $600 \mathrm{~nm}$. The level of lipid peroxidation [Malondialdehyde (MDA) equivalent] was then calculated as follows: $\frac{A_{532}-A_{600}}{15,5000} \times 10^{6}$, where $A_{532}$ is absorbance at $532 \mathrm{~nm}$ and $A_{600}$ is absorbance at $600 \mathrm{~nm}$. The results were expressed as nanomole MDA/g fresh weight of tissue sample. 


\section{Membrane stability assay}

The membrane stability index was measured as the relative percentage of total electrolyte leakage (Rady 2011). A total of $0.2 \mathrm{~g}$ shrimp tissue was washed with double distilled water and placed in a test tube containing $10 \mathrm{~mL}$ of double distilled water and incubated at $40{ }^{\circ} \mathrm{C}$ for $30 \mathrm{~min}$, after which the first reading of conductivity was registered (C1). The sample was then boiled for $10 \mathrm{~min}$ at $100{ }^{\circ} \mathrm{C}$ and cooled at room temperature before conductivity readings were taken (C2) using EUTECH INSTRUMENT PC700 $\mathrm{pH} / \mathrm{mV} / \mathrm{Conductivity} /{ }^{\circ} \mathrm{C} /{ }^{\circ} \mathrm{F}$ meter. Percentage of leakage was calculated as follows: Relative leakage $(\%$ leakage $)=\frac{1-C_{1}}{C_{2}} \times 100$, where $C_{1}$ is conductivity before boiling and $C_{2}$ is conductivity after boiling.

\section{Statistical analysis}

The collected data from antioxidant chemical assays, proximate analysis, survival, growth and oxidative stress biomarkers assay were analyzed using one-way analysis of variance (ANOVA) and the significant differences among treatments were determined using Tukey test at $95 \%$ confidence interval level. All statistical analysis was carried out using the SPSS (Statistical Package for the Social Sciences) software.

\section{Results and discussion}

Antioxidant activity of the formulated diet

The antioxidant activity in all treatments is dependent on the concentration of Tetraselmis chuii in the diets (Table 1). T100 and T75 showed the highest antioxidant activity, scavenging effect on free radicals and FRAP compared to control $(\mathrm{CF})$ and other treatments $(P \leq 0.05)$. In addition, there were no significant differences $(P \leq 0.05)$ between the antioxidant activity of T100 $(81.0 \pm 0.0 \%)$ with BHT $(80.4 \pm 1.2 \%)$, Trolox $(91.1 \pm 0.7 \%)$ and Ascorbic acid $(85.2 \pm 0.3 \%)$. The addition of $25 \%$ T. chuii (T25) (51.0 $\pm 0.0 \%)$ to commercial feed led to the increase of the antioxidant activity by 2.4 fold when compared to the feed without any $T$. chuii addition $(21.4 \pm 3.1 \%)$. A similar trend was also found regarding the scavenging effect on superoxide radical, DPPH radical and FRAP. The increase in the percentage of $T$. chuii into the feed led to the increase in the antioxidant properties of the feed. The addition of microalgae has been shown to increase the antioxidant compounds such as astaxanthin and lutein in the aquaculture feed (Li et al. 2015; Nonwachai et al. 2010). Due to the carcinogenic and tumorigenic nature of BHT, the potential of $T$. chuii as a natural source of antioxidants is very promising and can be considered as a substitute to replace the harmful synthetic substances.

Table 1 Antioxidant activity, free radical scavenging activities, and ferric reducing antioxidant potential (FRAP) of all formulated feed

\begin{tabular}{lllll}
\hline $\begin{array}{l}\text { Formulated } \\
\text { feed }\end{array}$ & $\begin{array}{l}\text { Antioxidant } \\
\text { activity }(\%)\end{array}$ & $\begin{array}{l}\text { Scavenging effect on superoxide } \\
\text { radical }(\%)\end{array}$ & $\begin{array}{l}\text { Scavenging effect on dpph } \\
\text { radical }(\%)\end{array}$ & $\begin{array}{l}\text { FRAP }(\mu \mathrm{m} \text { Trolox } \\
\left.\mathrm{g}^{-1}\right)\end{array}$ \\
\hline CF & $21.36 \pm 3.11^{\mathrm{d}}$ & $35.12 \pm 1.45^{\mathrm{e}}$ & $36.40 \pm 3.7^{\mathrm{d}}$ & $33.40 \pm 0.44^{\mathrm{e}}$ \\
$\mathrm{T} 25$ & $50.94 \pm 1.05^{\mathrm{c}}$ & $46.60 \pm 3.74^{\mathrm{d}}$ & $55.91 \pm 1.4^{\mathrm{c}}$ & $37.63 \pm 0.34^{\mathrm{d}}$ \\
T50 & $51.48 \pm 6.92^{\mathrm{c}}$ & $60.22 \pm 0.30^{\mathrm{c}}$ & $56.47 \pm 0.2^{\mathrm{c}}$ & $49.19 \pm 0.65^{\mathrm{c}}$ \\
T75 & $67.94 \pm 2.21^{\mathrm{b}}$ & $71.96 \pm 0.30^{\mathrm{b}}$ & $71.25 \pm 0.15^{\mathrm{b}}$ & $53.23 \pm 0.73^{\mathrm{b}}$ \\
T100 & $80.82 \pm 1.86^{\mathrm{a}, \mathrm{b}}$ & $77.85 \pm 0.14^{\mathrm{b}}$ & $74.64 \pm 0.35^{\mathrm{b}}$ & $60.28 \pm 0.62^{\mathrm{a}}$ \\
Trolox & $91.11 \pm 0.73^{\mathrm{a}}$ & $98.46 \pm 0.06^{\mathrm{a}}$ & $99.01 \pm 0.04^{\mathrm{a}}$ & - \\
Ascorbic & $85.18 \pm 0.32^{\mathrm{a}}$ & $95.66 \pm 0.26^{\mathrm{a}}$ & $97.85 \pm 0.11^{\mathrm{a}}$ & - \\
$\quad$ acid & $80.42 \pm 1.24^{\mathrm{a}}$ & $97.84 \pm 0.15^{\mathrm{a}}$ & $98.52 \pm 0.32^{\mathrm{a}}$ & - \\
\hline
\end{tabular}

Data shown are mean $\pm \mathrm{SE}(n=3)$. Means with the same letters are not significantly different 
Proximate composition of the formulated diet

The dried T. chuii (T100) contained $36.86 \pm 1.93 \%$ protein, $11.74 \pm 0.49 \%$ lipid and $20.83 \pm 0.65 \%$ carbohydrate (Table 2). For the formulated diet, the highest protein and lipid content was found in T50 with a total of $57.30 \pm 1.30$ and $13.98 \pm 0.67 \%$, respectively. Meanwhile, the highest carbohydrate content was shown by T100 and T75 which contained $20.83 \pm 0.65$ and $21.48 \pm 0.73 \%$, respectively.

The protein content (53-57\%) of the treatment feed CF, T25 and T50 in this study is well within the range recommended for growth and survival of shrimp postlarvae which should be greater than $44 \%$ (Biedenbach et al. 1989). The total lipid content and carbohydrate content of the formulated diet with $T$. chuii were also within the ranges recommended for shrimp. According to Bautista (1986), a protein content between 40 and $50 \%$, with $20 \%$ carbohydrate and 5-10\% lipid, provided the best growth and survival to the shrimp, Penaeus monodon. Thus, the addition of $T$. chuii to the feed for growing shrimp PL could provide adequate amounts of nutrients needed, and be a good source of the antioxidant.

Effect of T. chuii as feed additives on physical and chemical parameter of water from culture tank

In shrimp hatchery, increased TAN and $\mathrm{NO}_{2}-\mathrm{N}$ level with culture time are important factors that affect the survival, health and growth performance of shrimp postlarvae (Chin and Chen 1987). In this study, the inclusion of $T$. chuii into the feed leads to the improvement and maintenance of good water quality throughout the PL culture. Significantly lower TAN (Fig. 1a), $\mathrm{NO}_{2}-\mathrm{N}$ (Fig. 1b) and $\mathrm{PO}_{4}-\mathrm{P}$ (Fig. 1c) were found in water samples from the tank of PL supplemented with $T$. chuii compared to control during the final day of culture. This result was in accordance with Guedes and Malcata (2012), who showed that microalgae could stabilize and improve the water quality of culture. Although freeze-dried microalgae were used in this study, there are still some viable microalgal cells present even if it is at a very low level (Day 2007). Thus, there is a possibility of microalgal cells from leftover feed to start growing again in the tank. Throughout the shrimp culture period, a slow increase in green water concentration in the tank was observed. It was contributed by the increase in microalgae concentration which absorbs the nutrients available, especially in tank T50, T75 and T100. According to Chen et al. (2012), T. chuii showed the highest TAN uptake which led to lower nutrient toward the end of culture compared to the other microalgae species studied. Thus, minimal or no water exchange can be considered on PL fed with $T$. chuii inclusion which is beneficial due to the cost and labor usually needed for frequent water exchange in aquaculture to maintain a good water quality (Thompson et al. 2002). Meanwhile, there was no significant difference in the physical parameters (temperature, salinity, light and $\mathrm{pH}$ ) of the water for all treatments during the whole experimental period (Table 3).

Growth, survival and oxidative stress biomarkers of shrimp PL supplemented with high antioxidant T. chuii

Antioxidant in microalgae is mainly contributed by its bioactive compounds such as carotenoid, amino acids, polyunsaturated fatty acids and others. Even though the nutritional and antioxidant composition of feed will be high with higher concentration of microalgae, there is only a certain level of microalgae inclusion that can be tolerated by shrimp. This is because, increasing microalgae level led to the increase in fiber content, as well as lowering the digestibility and palatability of the feed (Sudaryono et al. 1996). In the feeding trials with the $L$.

Table 2 Proximate composition (\% dry weight) of formulated diets

\begin{tabular}{lllc}
\hline Formulated feed & Total protein $(\% \mathrm{dw})$ & Total lipid $(\% \mathrm{dw})$ & Total carbohydrate $(\% \mathrm{dw})$ \\
\hline CF & $53.47 \pm 0.75^{\mathrm{b}}$ & $11.95 \pm 0.40^{\mathrm{b}}$ & $9.10 \pm 0.60^{\mathrm{d}}$ \\
T25 & $54.64 \pm 1.09^{\mathrm{b}}$ & $13.48 \pm 0.54^{\mathrm{a}}$ & $15.53 \pm 0.72^{\mathrm{c}}$ \\
T50 & $57.30 \pm 1.30^{\mathrm{a}}$ & $13.98 \pm 0.67^{\mathrm{a}}$ & $18.09 \pm 0.72^{\mathrm{b}}$ \\
T75 & $11.89 \pm 0.44^{\mathrm{b}}$ & $21.48 \pm 0.73^{\mathrm{a}}$ \\
T100 & $43.63 \pm 2.32^{\mathrm{c}}$ & $11.74 \pm 0.49^{\mathrm{b}}$ & $20.83 \pm 0.65^{\mathrm{a}}$ \\
\hline
\end{tabular}

Data shown are mean $\pm \mathrm{SE}(n=3)$. Means with the same letters are not significantly different $(P>0.05)$ 


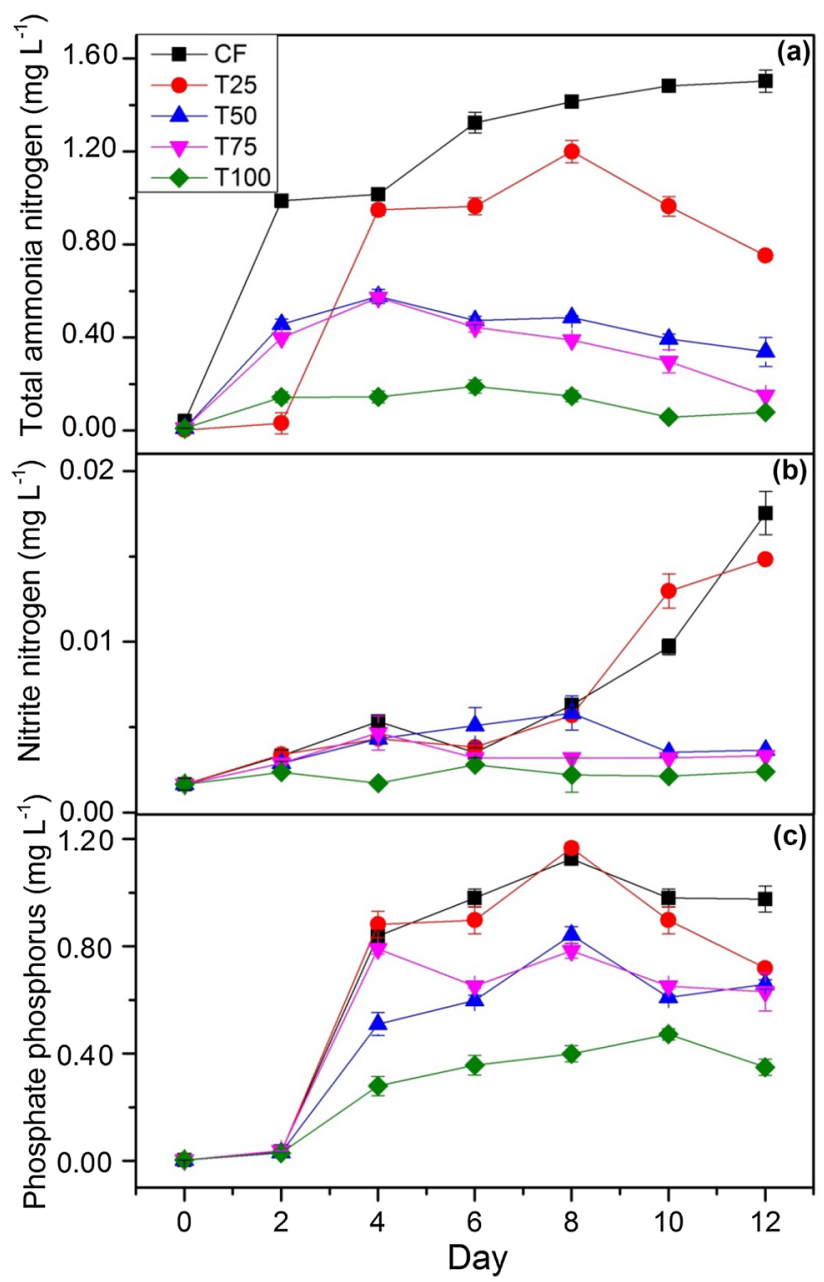

Fig. 1 a Total ammonia nitrogen, b nitrite nitrogen, c phosphate phosphorus concentrations of water in tanks with different formulated diet treatments compared to the control. Data shown are mean $\pm \operatorname{SE}(n=3)$

Table 3 Temperature, dissolved oxygen, $\mathrm{pH}$ and salinity in control and treated tanks

\begin{tabular}{llllr}
\hline Treatment & \multicolumn{3}{l}{ Parameter } & \\
\cline { 2 - 5 } & Temperature $\left({ }^{\circ} \mathrm{C}\right)$ & DO $\left(\mathrm{mg} \mathrm{L}^{-1}\right)$ & $\mathrm{pH}$ & Salinity $(\mathrm{ppt})$ \\
\hline $\mathrm{CF}$ & $26.99 \pm 0.16^{\mathrm{a}}$ & $5.78 \pm 0.10^{\mathrm{a}}$ & $8.32 \pm 0.03^{\mathrm{a}}$ & $30.25 \pm 0.07^{\mathrm{a}}$ \\
T25 & $27.10 \pm 0.07^{\mathrm{a}}$ & $5.73 \pm 0.12^{\mathrm{a}}$ & $8.28 \pm 0.06^{\mathrm{a}}$ & $30.31 \pm 0.14^{\mathrm{a}}$ \\
T50 & $27.12 \pm 0.17^{\mathrm{a}}$ & $5.54 \pm 0.14^{\mathrm{a}}$ & $8.30 \pm 0.05^{\mathrm{a}}$ & $30.23 \pm 0.08^{\mathrm{a}}$ \\
T75 & $27.05 \pm 0.15^{\mathrm{a}}$ & $5.83 \pm 0.11^{\mathrm{a}}$ & $8.31 \pm 0.04^{\mathrm{a}}$ & $30.21 \pm 0.09^{\mathrm{a}}$ \\
T100 & $27.12 \pm 0.26^{\mathrm{a}}$ & $5.95 \pm 0.22^{\mathrm{a}}$ & $8.31 \pm 0.07^{\mathrm{a}}$ & $30.34 \pm 0.10^{\mathrm{a}}$
\end{tabular}

Data shown are mean \pm SE $(n=3)$ for the whole 12 days of postlarvae culture. Means with the same letters are not significantly different $(P>0.05)$

vannamei postlarvae, the inclusion of $T$. chuii into the diet has shown a significantly higher survival compared to PL fed with commercial feed (control) after 12 days of culture period (Fig. 2). In Malaysia, the survival rate of PL at commercial hatchery is usually between 40 and $70 \%$, depending on the system used. In this study, the highest $(P \leq 0.05)$ survival of shrimp was achieved in tanks of PL fed with T50 $(97.6 \pm 1.4 \%)$ and followed by T75 $(85.6 \pm 3.5 \%)$. Meanwhile, along with a lower survival rate, PL fed with CF and T25 also showed a lethargic movement and was less active than PL fed with T50, T75 and T100. In terms of SGR, no significant 


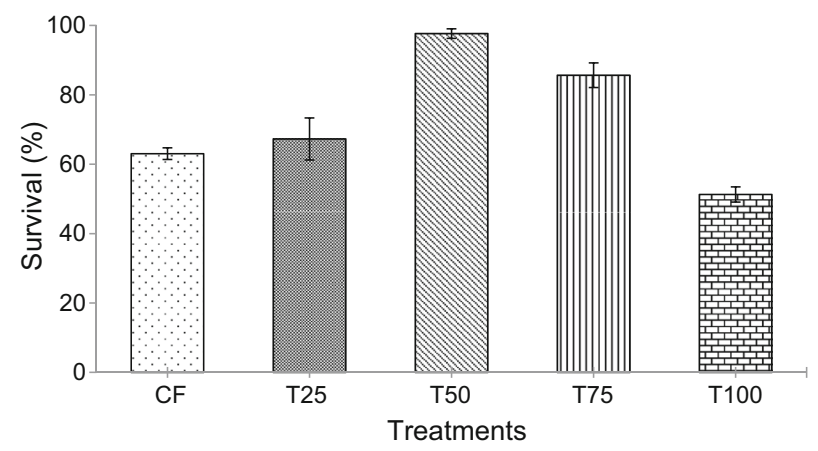

Fig. 2 Survival of postlarvae fed with formulated diets after a culture period of 12 days. Data shown are mean \pm SE $(n=3)$

Table 4 Specific growth rate (SGR) of shrimp postlarvae fed with formulated diets

\begin{tabular}{ll}
\hline Treatment & Specific growth rate, SGR \\
\hline CF & $27.92 \pm 0.88^{\mathrm{a}}$ \\
T25 & $26.76 \pm 0.92^{\mathrm{a}}$ \\
T50 & $26.60 \pm 0.70^{\mathrm{a}}$ \\
T75 & $22.16 \pm 0.32^{\mathrm{a}}$ \\
T100 & $23.20 \pm 1.43^{\mathrm{a}}$ \\
\hline
\end{tabular}

Data shown are mean $\pm \mathrm{SE}(n=3)$. Means with the same letters within column are not significantly different at $P<0.05$

difference $(P>0.05)$ was observed among all treatments (Table 4). The performance and health of the aquatic organism are directly related to the excessive production of ROS and protection of the cell membrane by antioxidant against the production of free radical (Mourente et al. 2002). In this study, the higher survival of PL supplemented with $T$. chuii can be linked to the hydrogen peroxide content $\left(\mathrm{H}_{2} \mathrm{O}_{2}\right)$, lipid peroxidation and electrolyte leakage which act as the biomarkers of the oxidative stress in the shrimp tissue.

Postlarvae fed with the addition of $T$. chuii in their diet showed lower $\mathrm{H}_{2} \mathrm{O}_{2}$ compared to $\mathrm{CF}$ (Fig. 3a). The $\mathrm{H}_{2} \mathrm{O}_{2}$ content in PL fed with T75 $\left(10.22 \pm 0.3 \mathrm{mM} \mathrm{g}^{-1} \mathrm{FW}\right)$ and T50 $\left(10.08 \pm 0.4 \mathrm{mM} \mathrm{g}^{-1} \mathrm{FW}\right)$ significantly decreased compared to CF, T25, and T100. This suggests that the inclusion of $T$. chuii into the PL diet up to $75 \% \mathrm{~T}$. chuii presented a protective effect against oxidative stress in the shrimp under both stressful situations and also during development to protect the cell. This result is in accordance with Amar et al. (2004), who reported that the antioxidant defense in an aquatic organism depends on the nutritional factors. High supplementation of dietary antioxidant caused a reduced need for the endogenous antioxidant enzyme (such as catalase and superoxide dismutase) in scavenging hydrogen peroxide $\left(\mathrm{H}_{2} \mathrm{O}_{2}\right)$ and superoxide radical (Lygren et al. 1999). In accordance with the study by Sheikhzadeh et al. (2012) and Da Silva et al. (2015), supplementation of the high astaxanthin $H$. pluvialis into feed also leads to better performance with increased antioxidant activity in juvenile L. vannamei.

The degree of cell membrane injury induced by oxidative stress was measured as the relative percentage of total electrolyte leakage from the cells (Fig. 3b). In the present study, the lowest electrolyte leakage was found in PL fed with T50 $(10.8 \pm 0.3 \%)$ which was significantly lower $(P \leq 0.05)$ than CF, T25, and T100. There were no significant differences $(P>0.05)$ in the electrolyte leakage between PL fed with T50 $(10.8 \pm 0.3 \%)$ and $\mathrm{T} 75(12.7 \pm 1.0 \%)$. It was found that with the inclusion of $T$. chuii to the PL diet, the electrolyte leakage decreased compared to control. However, the addition of T. chuii of more than $75 \%$ led to the increase in the electrolyte leakage of the PL. In cells, stress-induced electrolyte leakage is caused by the accumulation of ROS such as $\mathrm{H}_{2} \mathrm{O}_{2}$ and often results in decreased membrane permeability and programmed cell death (Neill et al. 2002; Demidchik et al. 2014). Both animal and plant showed similar mechanism with the ROS-activated $\mathrm{K}^{+}$permeable cation channel in the cell membrane, which is a major parameter in regulating the programmed cell death (Demidchik et al. 2014). The addition of T. chuii is capable of protecting the cells from cell damage and death by neutralizing the ROS into safer intermediates before it can cause further damages to the cell. 

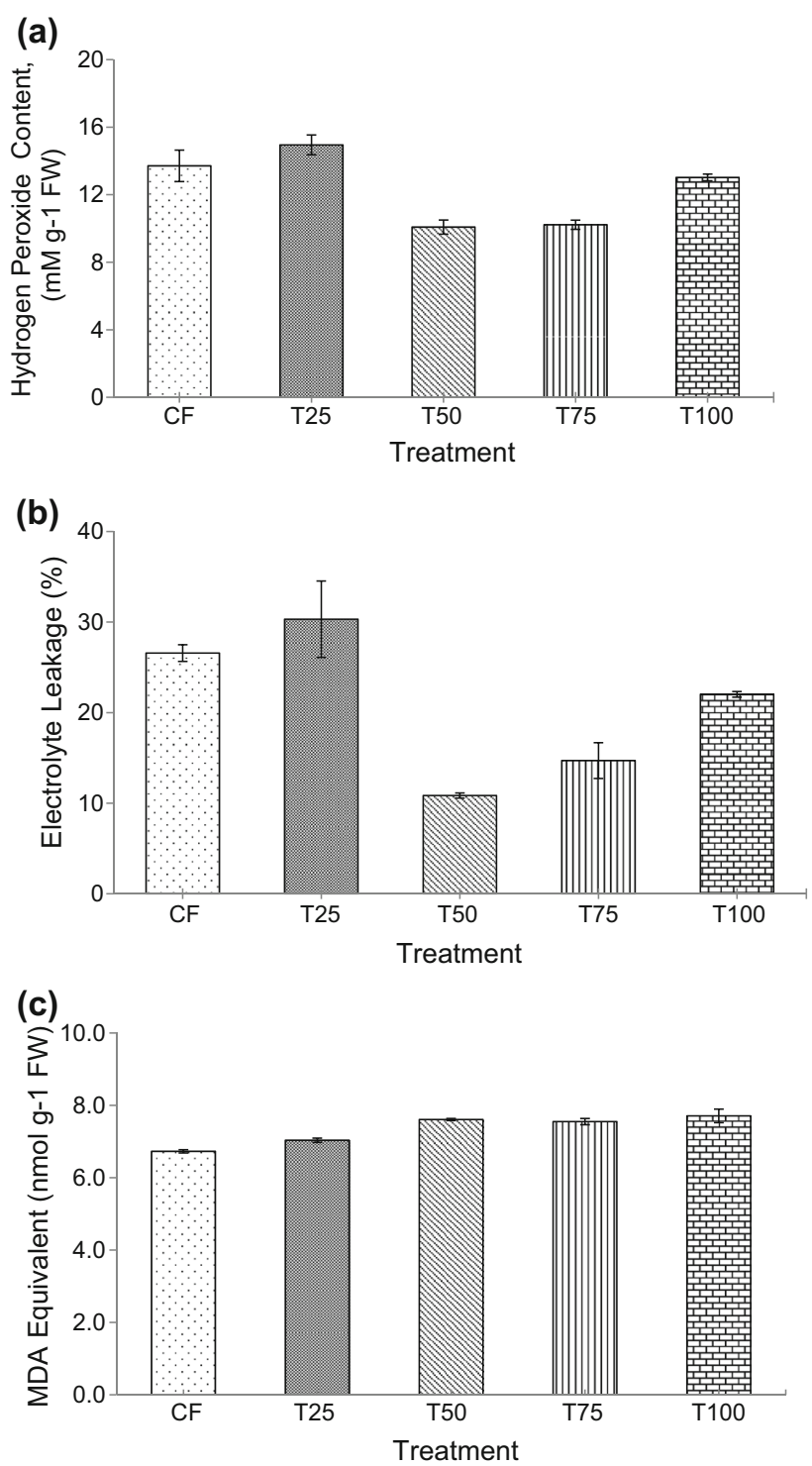

Fig. 3 a Hydrogen peroxide content, $\mathbf{b}$ electrolyte leakage, $\mathbf{c}$ lipid peroxidation of postlarvae fed with formulated diets after a culture period of 12 days. Data shown are mean $\pm \operatorname{SE}(n=3)$

Lipid peroxidation was measured by determination of malondialdehyde (MDA) as an end product of lipid peroxidation. In this study, the lipid peroxidation in the PL did not differ significantly $(P>0.05)$ between all treatments (Fig. 3c). According to Tirmenstein and Reed (1988), during exposure to stress, lipid peroxidation can cause subcellular organelles and biomembrane damage. Although no significant difference was observed in the lipid peroxidation among all treatment, based on the $\mathrm{H}_{2} \mathrm{O}_{2}$, electrolyte leakage and the survival of the PL, the results suggest that without the enrichment of the diet with the high antioxidant $T$. chuii, the PL seem to be more highly susceptible to oxidative stress, which led to cell damage and death. The lower survival of CF and T25 treatment (Fig. 2) is probably due to the high rate of cell damage and death that occurred throughout the culture period. Survived PL in the CF tank may have adapted or had more intact cell membranes by the end of culture period, leading to lower lipid peroxidation in the PL. Ruff et al. (2001) also reported no significant difference in the lipid peroxidation of PL supplemented with dietary tocopherol and ascorbic acid to the lipid peroxidation. Thus, the present study showed that the inclusion of $T$. chuii led to better protection against oxidative stress and oxidative damages by improving the cells scavenging effect on ROS, which resulted in higher survival with low $\mathrm{H}_{2} \mathrm{O}_{2}$ content and electrolyte leakage compared to $\mathrm{CF}$. 


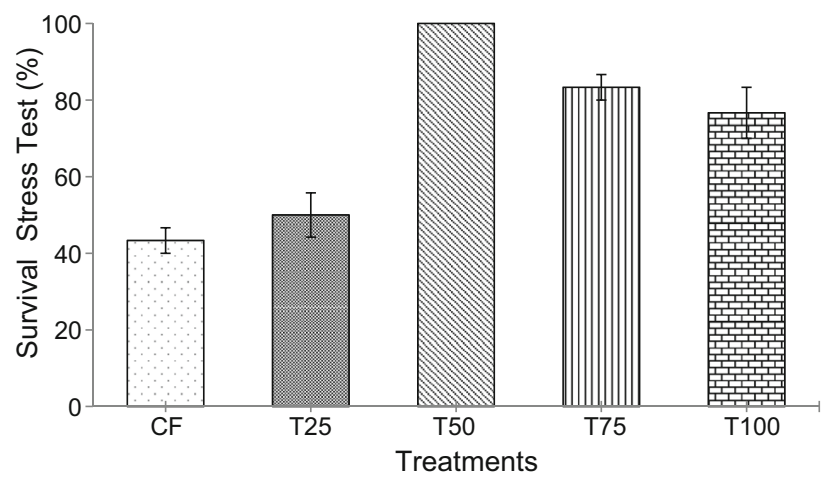

Fig. 4 Survival after salinity stress test in larval rearing tanks after a culture period of 12 days. Data shown are mean \pm SE $(n=3)$

Postlarvae fed with T. chuii also showed a higher resistance against exposure to salinity stress (Fig. 4). In aquatic organisms, changes in salinity may cause a variety of physiological stress, energy metabolism, electrolyte equilibrium and enhanced ROS generation which leads to oxidative damage (Choi et al. 2008). After $2 \mathrm{~h}$ of exposure to freshwater, PL fed a diet enriched with $T$. chuii showed a significantly higher survival against salinity stress compared to the control. Interestingly, $100 \%$ survival was exhibited by PL fed with $50 \%$ T. chuii (T50) and followed by T75. In fact, all PL fed with T50 were still alive and active even after $4 \mathrm{~h}$ of exposure to freshwater. No survival was observed after $4 \mathrm{~h}$ of exposure in PL fed with CF and T25.

The present study showed that the addition of $T$. chuii with high antioxidant properties into the PL diet at $50-75 \%$ is very beneficial and it enhances the PL defense against excessive oxygen radicals during normal physiological conditions and upon exposure to stress. This is because, under reduced salinity, there is a potential for excessive production of oxygen radicals in shrimp to maintain osmotic stability. The present study showed that the supplementation of $T$. chuii with high antioxidant properties could increase the defense of the PL against oxidative stress and damage, thereby leading to a higher survival rate and a higher tolerance against stress. In addition, supplementation with $T$. chuii also provides adequate nutrient to the PL and improvement in water quality throughout the culture period.

\section{Conclusions}

The present study demonstrated that supplementation with 50\% T. chuii which have high antioxidant properties could improve the survival of the shrimp PL as well as maintain the water quality. In addition, it also enhances the shrimp defense against oxidative stress and damages by improving the cells scavenging effect on ROS, which led to a higher PL survival, with a lower $\mathrm{H}_{2} \mathrm{O}_{2}$ content, electrolyte leakage and higher tolerance against stress. Therefore, the present findings indicate the potential application of this microalgal species as a valuable natural antioxidant source that can be utilized for $L$. vannamei postlarvae.

Acknowledgements This study was supported by the Ministry of Higher Education, Malaysia, through the Fundamental Research Grant Scheme (FRGS) Project no. FRGS/1/2015/WAB01/UMT/03/6.

Open Access This article is distributed under the terms of the Creative Commons Attribution 4.0 International License (http:// creativecommons.org/licenses/by/4.0/), which permits unrestricted use, distribution, and reproduction in any medium, provided you give appropriate credit to the original author(s) and the source, provide a link to the Creative Commons license, and indicate if changes were made.

\section{References}

AbouL-Enein AM, El-Baz FK, El-Baroty GS, Youssef AM, Abd El-Baky HH (2003) Antioxidant activity of algal extracts on lipid peroxidation. J Med Sci 3:87-98

Amar EC, Kiron V, Satoh S, Watanabe T (2004) Enhancement of innate immunity in rainbow trout (Oncorhynchus mykiss Walbaum) associated with dietary intake of carotenoids from natural products. Fish Shellfish Immun 16:527-537 
Bachère E (2000) Shrimp immunity and disease control. Aquaculture 191:3-11

Bautista MN (1986) The response of Penaeus monodon juveniles to varying protein/energy ratios in test diets. Aquaculture 53:229-242

Biedenbach JM, Smith LL, Thomsen TK, Lawrence AL (1989) Use of the Nematode Panagrellus redivivus as an artemia replacement in a larval penaeid diet. J World Aquacult Soc 20:61-71

Bligh EG, Dyer WJ (1959) A rapid method of total lipid extraction and purification. Can J Biochem Physiol 37:911-917

Carballo-Cárdenas EC, Tuan PM, Janssen M, Wijffels RH (2003) Vitamin E ( $\alpha$-tocopherol) production by the marine microalgae Dunaliella tertiolecta and Tetraselmis suecica in batch cultivation. Biomol Eng 20:139-147

Castex M, Lemaire P, Wabete N, Chim L (2010) Effect of probiotic Pediococcus acidilactici on antioxidant defences and oxidative stress of Litopenaeus stylirostris under Vibrio nigripulchritudo challenge. Fish Shellfish Immun 28:622-631

Chen SY, Pan LY, Hong MJ, Lee AC (2012) The effects of temperature on the growth of and ammonia uptake by marine microalgae. Bot Stud 53:125-133

Chin TS, Chen JC (1987) Acute toxicity of ammonia to larvae of the tiger prawn, Penaeus monodon. Aquaculture 66:247-253

Choi CY, An KW, An MI (2008) Molecular characterization and mRNA expression of glutathione peroxidase and glutathione S-transferase during osmotic stress in olive flounder (Paralichthys olivaceus). Comp Biochem Phys A 149:330-337

Da Silva FO, Tramonte VLCG, Parisenti J, Lima-Garcia JF, Maraschin M, da Silva EL (2015) Litopenaeus vannamei muscle carotenoids versus astaxanthin: a comparison of antioxidant activity and in vitro protective effects against lipid peroxidation. Food Biosci 9:12-19

Day JG (2007) Cryopreservation of microalgae and cyanobacteria. In: Day JG, Stacey GN (eds) Cryopreservation and freezedrying protocols, 2nd edn. Humana, Totowa, pp 39-58

Demidchik V, Straltsova D, Medvedev SS, Pozhvanov GA, Sokolik A, Yurin V (2014) Stress-induced electrolyte leakage: the role of K+-permeable channels and involvement in programmed cell death and metabolic adjustment. J Exp Bot 65:1259-1270

Di Giulio RT, Benson WH, Sanders BM, Van Veld PA (1995) Biochemical mechanisms: Metabolism, adaptation and toxicity. Fundamentals of aquatic toxicology, 2nd edn. Taylor and Francis, Washington, pp 523-561

Dubois M, Gilles KA, Hamilton JK, Rebers PA, Smith F (1956) Colorimetric method for determination of sugars and related substances. Anal Chem 28:350-356

Gamboa-Delgado J, Le Vay L (2009) Artemia replacement in co-feeding regimes for mysis and postlarval stages of Litopenaeus vannamei: nutritional contribution of inert diets to tissue growth as indicated by natural carbon stable isotopes. Aquaculture 297:128-135

Geetha BV, Navasakthi R, Padmini E (2010) Investigation of antioxidant capacity and phytochemical composition of sun Chlorella - an in vitro study. J Aquac Res Development 1:1-7

Guedes AC, Malcata FX (2012) Nutritional value and uses of microalgae in aquaculture. In: Muchlisin Z (ed) Aquaculture. INTECH Open Acess Publisher, pp 59-78

Gyamfi MA, Yonamine M, Aniya Y (1999) Free-radical scavenging action of medicinal herbs from Ghana. Gen Pharmacol-Vasc S 32:661-667

Hajimahmoodi M, Faramarzi M, Mohammadi N, Soltani N, Oveisi M, Nafissi-Varcheh N (2010) Evaluation of antioxidant properties and total phenolic contents of some strains of microalgae. J Appl Phycol 22:43-50

Heath RL, Packer L (1968) Photoperoxidation in isolated chloroplasts. I. Kinetics and stoichiometry of fatty acid peroxidation. Arch Biochem Biophys 125:189-198

Ismaiel MM, El-Ayouty YM, Piercey-Normore M (2016) Role of pH on antioxidants production by Spirulina (Arthrospira) platensis. Braz J Microbiol 47(2):298-304

Jahnke LS (1999) Massive carotenoid accumulation in Dunaliella bardawil induced by ultraviolet-A radiation. J Photochem Photobiol B 48:68-74

Ju ZY, Deng DF, Dominy WG, Forster IP (2011) Pigmentation of Pacific white shrimp, Litopenaeus vannamei, by dietary Astaxanthin extracted from Haematococcus pluvialis. J World Aquac Soc 42:633-644

Ju ZY, Deng DF, Dominy WG (2012) A defatted microalgae (Haematococcus pluvialis) meal as a protein ingredient to partially replace fishmeal in diets of Pacific white shrimp (Litopenaeus vannamei, Boone, 1931). Aquaculture 354-355:50-55

Khatoon H, Yusoff FM, Banerjee S, Shariff M, Mohamed S (2007) Use of periphytic cyanobacterium and mixed diatoms coated substrate for improving water quality, survival and growth of Penaeus monodon Fabricius postlarvae. Aquaculture 271:196-205

Khatoon H, Abdu Rahman N, Banerjee S, Harun N, Suleiman SS, Zakaria NH, Lananan F, Abdul Hamid SH, Endut A (2014) Effects of different salinities and $\mathrm{pH}$ on the growth and proximate composition of Nannochloropsis sp. and Tetraselmis sp. isolated from South China Sea cultured under control and natural condition. Int Biodeterior Biodegradation 95:11-18

Li M, Wu W, Zhou P, Xie F, Zhou Q, Mai K (2014) Comparison effect of dietary astaxanthin and Haematococcus pluvialis on growth performance, antioxidant status and immune response of large yellow croaker Pseudosciaena crocea. Aquaculture 434:227-232

Li Y, Xiao G, Mangott A, Kent M, Pirozzi I (2015) Nutrient efficacy of microalgae as aquafeed additives for the adult black tiger prawn, Penaeus monodon. Aquac Res 47(11):1-11

Lightner DV (2011) Virus diseases of farmed shrimp in the Western Hemisphere (the Americas): a review. J Invertebr Pathol 106:110-130

Liu Y, Wang WN, Wang AL, Wang JM, Sun RY (2007) Effects of dietary vitamin E supplementation on antioxidant enzyme activities in Litopenaeus vannamei (Boone, 1931) exposed to acute salinity changes. Aquaculture 265:351-358

Lowry OH, Rosebrough NJ, Farr AL, Randall RJ (1951) Protein measurement with the Folin phenol reagent. J Biol Chem 193:265-275

Lushchak VI (2011) Environmentally induced oxidative stress in aquatic animals. Aquat Toxicol 101:13-30 
Lygren B, Hamre K, Waagbo R (1999) Effects of dietary pro- and antioxidants on some protective mechanisms and health parameters in Atlantic salmon. J Aquat Anim Health 11:211-221

Macias-Sancho J, Poersch LH, Bauer W, Romano LA, Wasielesky W, Tesser MB (2014) Fishmeal substitution with Arthrospira (Spirulina platensis) in a practical diet for Litopenaeus vannamei: effects on growth and immunological parameters. Aquaculture 426-427:120-125

Marsh JB, Weinstein DB (1966) Simple charring method for determination of lipids. J Lipid Res 7(4):574-576

Mourente G, Díaz-Salvago E, Bell J, Tocher D (2002) Increased activities of hepatic antioxidant defence enzymes in juvenile gilthead sea bream (Sparus aurata L.) fed dietary oxidised oil: attenuation by dietary vitamin E. Aquaculture 214:343-361

Neill S, Desikan R, Hancock J (2002) Hydrogen peroxide signalling. Curr Opin Plant Biol 5:388-395

Nonwachai T, Purivirojkul W, Limsuwan C, Chuchird N, Velasco M, Dhar AK (2010) Growth, nonspecific immune characteristics, and survival upon challenge with Vibrio harveyi in Pacific white shrimp (Litopenaeus vannamei) raised on diets containing algal meal. Fish Shellfish Immunol 29:298-304

Parsons TR, Maita Y, Lalli CM (1984) A manual of chemical and biological methods for seawater analysis. Pergamon Press, New York, p 173

Rady MM (2011) Effect of 24-epibrassinolide on growth, yield, antioxidant system and cadmium content of bean (Phaseolus vulgaris L.) plants under salinity and cadmium stress. Sci Hortic-Amsterdam 129:232-237

Rao AR, Sarada R, Baskaran V, Ravishankar GA (2006) Antioxidant activity of Botryococcus braunii extract elucidated in vitro models. J Agr Food Chem 54:4593-4599

Ricker WE (1990) Growth rates and models. In: Hoar WS, Randal DJ, Brett JR (eds) Fish Physiology, vol VIII. Academic Press, USA, Bio- energetic and Growth, p 230

Robak J, Gryglewski RJ (1988) Flavonoids are scavengers of superoxide anions. Biochem Pharmacol 37:837-841

Ruff N, Lavens P, Huo JZ, Sorgeloos P, Nelis HJ, De Leenheer A (2001) Antioxidant effect of dietary tocopherol and ascorbic acid on growth and survival of Litopenaeus vannamei postlarvae. Aquac Int 9:115-126

Sheikhzadeh N, Tayefi-Nasrabadi H, Khani Oushani A, Najafi Enferadi M (2012) Effects of Haematococcus pluvialis supplementation on antioxidant system and metabolism in rainbow trout (Oncorhynchus mykiss). Fish Physiol Biochem 38:413-419

Shimada K, Fujikawa K, Yahara K, Nakamura T (1992) Antioxidative properties of xanthan on the autoxidation of soybean oil in cyclodextrin emulsion. J Agr Food Chem 40:945-948

Sudaryono A, Tsvetnenko E, Evans LH (1996) Digestibility studies on fisheries by product based diets for Penaeus monodon. Aquaculture 143:331-340

Thompson FL, Abreu PC, Wasielesky W (2002) Importance of biofilm for water quality and nourishment in intensive shrimp culture. Aquaculture 203:263-278

Tirmenstein MA, Reed DJ (1988) Characterization of glutathione-dependent inhibition of lipid peroxidation of isolated rat liver nuclei. Arch Biochem Biophys 261:1-11

Tompkins J, Deville MM, Day JG, Turner MF (1995) Catalogue of Strains. Titus Wilson and Son Ltd. Kendall. UK, p 166

Velikova V, Yordanov I, Edreva A (2000) Oxidative stress and some antioxidant systems in acid rain-treated bean plants protective role of exogenous polyamines. Plant Sci 151:59-66

Yang JH, Mau JL, Ko PT, Huang LC (2000) Antioxidant properties of fermented soybean broth. Food Chem 71:249-254 